\author{
A.S. Erdogan ${ }^{1}$, D. Kusmangazinova ${ }^{2}$, I. Orazov $^{3,4}$, M.A. Sadybekov ${ }^{4}$ \\ ${ }^{1}$ Sigma Labs Florida, Orlando, USA; \\ ${ }^{2}$ Al-Farabi Kazakh National University, Almaty, Kazakhstan; \\ ${ }^{3}$ M. Auezov South Kazakhstan State University, Shymkent, Kazakhstan; \\ ${ }^{4}$ Institute of Mathematics and Mathematical Modeling, Almaty, Kazakhstan \\ (E-mail:aserdogan@gmail.com)
}

\title{
On one problem for restoring the density of sources of the fractional heat conductivity process with respect to initial and final temperatures
}

\begin{abstract}
In this paper we consider inverse problems for a fractional heat equation, where the fractional time derivative is taken into account in Riemann-Liouville sense. For the solution of this equation, we have to find an unknown right-hand side depending only on a spatial variable. The problem modeling the process of determining the temperature and density of sources in the process of fractional heat conductivity with respect to given initial and final temperatures is considered. Problems with general boundary conditions with respect to the spatial variable that are not strongly regular are investigated. The existence and uniqueness of classical solution to the problem are proved. The problem is considered independent from a corresponding spectral problem for an operator of multiple differentiation with not strongly regular boundary conditions has the basis property of root functions.
\end{abstract}

Keywords: Inverse problem, heat equation, fractional heat conductivity, not strongly regular boundary conditions, method of separation of variables.

\section{Introduction}

It is well-known that problems of determining coefficients or the right-hand side of a differential equation simultaneously with its solution are called inverse problems of mathematical physics. These problems often arise in various areas (seismology, exploration of minerals, biology, medicine, quality control of industrial products etc.) that place them among the current problems of modern mathematics.

In this article, we consider a class of problems which model the process of determining the temperature and density of heat sources with respect to given initial and final temperatures. Their mathematical statement leads to the inverse problems for a fractional heat equation in which along with solving the equation we have to find an unknown right-hand side depending only on a spatial variable.

The questions of solvability of various inverse problems for parabolic equations were studied in many articles. The closest to the subject of this paper is [1], in which one case of regular but not strongly regular boundary conditions was considered. The analysis was carried out by the Fourier method using a basis of eigenfunctions and associated functions. In contrast to this (and other) article, we study the inverse problems for the fractional heat equation with general boundary conditions with respect to the spatial variable which are regular but not strongly regular.

Let $\Omega=\{(x, t), 0<x<1,0<t<T\}$. In $\Omega$ we consider a problem of finding the right-hand side $f(x)$ of the fractional heat equation

$$
D_{0+}^{\alpha}(u(x, t)-u(x, 0))-u_{x x}(x, t)=f(x)+F(x, t),(x, t) \in \Omega
$$

and its solutions $u(x, t)$ satisfying the initial and final conditions

$$
u(x, 0)=\varphi(x), \quad u(x, T)=\psi(x), 0 \leq x \leq 1,
$$

and the boundary conditions

$$
\left\{\begin{array}{l}
a_{1} u_{x}(0, t)+b_{1} u_{x}(1, t)+a_{0} u(0, t)+b_{0} u(1, t)=0 ; \\
c_{1} u_{x}(0, t)+d_{1} u_{x}(1, t)+c_{0} u(0, t)+d_{0} u(1, t)=0 .
\end{array}\right.
$$


The coefficients $a_{k}, b_{k}, c_{k}, d_{k}$ with $k=0,1$ in (3) are real numbers, $D_{0+}^{\alpha}$ stands for the Riemann-Liouville fractional derivative of order $0<\alpha<1$ :

$$
D_{0+}^{\alpha} y(t)=\frac{1}{\Gamma(1-\alpha)} \frac{d}{d t} \int_{0}^{t} \frac{y(s) d s}{(t-s)^{\alpha}},
$$

while $\varphi(x), \psi(x)$ and $F(x, t)$ are given functions.

Definition. By a regular solution of the inverse problem (1)-(3) we mean a pair of functions $(u(x, t), f(x))$ of the class $u(x, t) \in C_{x, t}^{2,1}(\bar{\Omega}), f(x) \in C[0,1]$ that inverts equation (1) and conditions (2)-(3) into an identity.

The use of the Fourier method for solving problem (1)-(3) leads to the spectral problem for the operator $\ell$ given by the differential expression $\ell(y)=-y^{\prime \prime}(x), \quad 0<x<1$ and boundary conditions

$$
\left\{\begin{array}{l}
a_{1} y^{\prime}(0)+b_{1} y^{\prime}(1)+a_{0} y(0)+b_{0} y(1)=0 \\
c_{1} y^{\prime}(0)+d_{1} y^{\prime}(1)+c_{0} y(0)+d_{0} y(1)=0 .
\end{array}\right.
$$

These boundary conditions are called regular [2] if one of the following three conditions

$$
\begin{aligned}
& \text { i. } \quad a_{1} d_{1}-b_{1} c_{1} \neq 0 ; \\
& \text { ii. } a_{1} d_{1}-b_{1} c_{1}=0, \quad\left|a_{1}\right|+\left|b_{1}\right|>0, a_{1} d_{0}+b_{1} c_{0} \neq 0 ; \\
& \text { iii. } a_{1}=b_{1}=c_{1}=d_{1}=0, a_{0} d_{0}-b_{0} c_{0} \neq 0
\end{aligned}
$$

is satisfied. Regular boundary conditions are strongly regular in the first and third cases, while in the second case this requires the additional condition

$$
a_{1} c_{0}+b_{1} d_{0} \neq \pm\left[a_{1} d_{0}+b_{1} c_{0}\right] .
$$

Particular cases of (1)-(3) were considered in [1] with boundary conditions (3) which are not strongly regular: the case of conditions of Samarskii-Ionkin type

$$
u(1, t)=0, \quad u_{x}(0, t)=u_{x}(1, t)
$$

and the case of periodic boundary conditions

$$
u(0, t)=u(1, t), \quad u_{x}(0, t)=u_{x}(1, t) .
$$

However, the method of proof of [1] does not automatically carry over to problems with arbitrary not strongly regular boundary conditions (3). This has essentially to do with the use in [1] of a basis of eigenfunctions and generalized eigenfunctions of the corresponding problem (4) for the operator of multiple differentiation. Unfortunately, not all problems of this type have the basis property. Therefore, in order to study the formulated problem, regardless of the basis properties of the system of root vectors of the operator $\ell$, we use the method first substantiated in our work [3]. In [3] a class of problems modeling the process of determining the temperature and density of heat sources with respect to given initial and final temperature is considered. To solve direct heat conductivity problems with general not strongly regular boundary conditions with respect to the spatial variable, this method is described in detail in [4].

The solvability of various inverse problems for parabolic equations was studied in papers of Yu.E. Anikonov and Yu.Ya. Belov, B.A. Bubnov, A.I. Prilepko and A.B. Kostin, V.N. Monakhov, A.I. Kozhanov, I.A. Kaliev, K.B. Sabitov and many others.

These citations can be seen in our papers [3] and [5]. We note [6-28] as recent papers close to the theme of our article. In these papers different variants of direct and inverse initial-boundary value problems for evolutionary equations are considered, including problems with nonlocal boundary conditions and problems for equations with fractional derivatives.

We solve the problem by the Fourier method. Some new variants for solving nonlocal boundary value problems by the method of separation of variables were used in our papers [29-35]. 


\section{Case of Sturm-type boundary conditions}

A particular case of strongly regular boundary conditions are Sturm-type conditions: $b_{0}=b_{1}=c_{0}=c_{1}=0$ :

$$
\left\{\begin{array}{l}
a_{1} u_{x}(0, t)+a_{0} u(0, t)=0 ; \\
d_{1} u_{x}(1, t)+d_{0} u(1, t)=0 .
\end{array}\right.
$$

By $\ell_{1}$ let us denote a corresponding ordinary differential operator arising when applying the method of separation of variables to problem (1), (2), (7). Spectral problem $\ell_{1} y=\lambda y$ has the form

$$
\begin{gathered}
\ell_{1}(y) \equiv-y^{\prime \prime}(x)=\lambda y(x), 0<x<1 ; \\
a_{1} y(0)+a_{0} y(0)=0, \quad d_{1} y(1)+d_{0} y(1)=0 .
\end{gathered}
$$

Denote by $\lambda_{k}$ the eigenvalues of the operator $\ell_{1}$ enumerated in the increasing order of their absolute values, and by $y_{k}(x)$, for $k=1,2, \ldots$, denote corresponding normalized eigenfunctions. It is known [2] that the eigenvalues of these problems are real and simple, while the system of their eigenfunctions forms an orthonormal basis in $L_{2}(0,1)$. Thus, we can represent the solution $u(x, t), f(x)$ to $(1),(2),(7)$ as the series:

$$
u(x, t)=\sum_{k=1}^{\infty} u_{k}(t) y_{k}(x), f(x)=\sum_{k=1}^{\infty} f_{k} y_{k}(x) .
$$

Substituting (9) into (1) and (2), we obtain the problems

$$
D_{0+}^{\alpha}\left(u_{k}(t)-u_{k}(0)\right)+\lambda_{k} u_{k}(t)=f_{k}+F_{k}(t), \quad u_{k}(0)=\varphi_{k}, \quad u_{k}(T)=\psi_{k}
$$

for finding the unknown functions $u_{k}(t)$ and coefficients $f_{k}$. Here $F_{k}(t), \varphi_{k}$ and $\psi_{k}$ are the Fourier coefficients of $F(x, t), \varphi$ and $\psi$ with respect to the system $\left\{y_{k}(x)\right\}$. Then we get

$$
F_{k}(t)=\left(F(x, t), y_{k}(x)\right), \varphi_{k}=\left(\varphi(x), y_{k}(x)\right) \text {, and } \psi_{k}=\left(\psi(x), y_{k}(x)\right) \text {. }
$$

The inverse problem (10) is investigated similarly, as in [1]. A solution to (10) exists, is unique, and can be written explicitly. Without dwelling on the details, we write out its solution:

$$
\begin{gathered}
u_{k}=\frac{\psi_{k}-U_{k}(T)-\varphi_{k} e_{\alpha}\left(T, \lambda_{k}\right)}{\gamma_{k}} \int_{0}^{t}(t-\tau)^{\alpha-1} e_{\alpha}\left(\tau, \lambda_{k}\right) d \tau+\varphi_{k} e_{\alpha}\left(t, \lambda_{k}\right)+U_{k}(t), \\
f_{k}=\Gamma(1+\alpha) \frac{\psi_{k}-U_{k}(T)-\varphi_{k} e_{\alpha}\left(T, \lambda_{k}\right)}{\alpha \gamma_{k}},
\end{gathered}
$$

where $U_{k}(t)$ is a solution of problem

$$
D_{0+}^{\alpha}\left(U_{k}(t)-U_{k}(0)\right)+\lambda_{k} U_{k}(t)=F_{k}(t), \quad U_{k}(0)=0 .
$$

In (11) and (12) function $e_{\alpha}(\tau, \mu)$ is expressed by the function of Mittag-Leffler:

$$
\begin{gathered}
e_{\alpha}(\tau, \mu):=E_{\alpha}\left(-\mu \tau^{\alpha}\right), \quad E_{\alpha}(z)=\sum_{k=0}^{\infty} \frac{z^{k}}{\Gamma(1+\alpha k)}, \alpha \in[0,+\infty), \\
\gamma_{k}=\int_{0}^{T}(T-\tau)^{\alpha-1} e_{\alpha}\left(\tau, \lambda_{k}\right) d \tau .
\end{gathered}
$$

The Mittag-Leffler function $e_{\alpha}(\tau, \mu)$ for $\mu>0$ and $0<\alpha \leq 1$ is absolutely monotone function with respect to $\tau$ (see $[36 ; 268])$. Since $e_{\alpha}\left(0, \lambda_{k}\right)=1$, then from (13) it is easy to see that there exists a constant $\widehat{\gamma}>0$ such that

$$
\gamma_{k} \geq \widehat{\gamma}>0, \forall k=1,2, \ldots
$$

Inserting (11) and (12) into (9), we arrive at a formal solution to the problem. In order to complete our study, it is necessary, as in the Fourier method, to justify the smoothness of the resulting formal solutions and the convergence of all appearing series. Let us state the main result of this section. 
Theorem 1. If $F(x, t) \in C^{2}(\bar{\Omega}), \varphi(x), \psi(x) \in C^{4}[0,1]$ and functions $F(x, t), \varphi(x), \psi(x), \varphi^{\prime \prime}(x)$ and $\psi^{\prime \prime}(x)$ satisfy (7), then there exists a unique classical solution $u(x, t) \in C_{x, t}^{2,1}(\bar{\Omega}), f(x) \in C[0,1]$ to the inverse problem (1), (2), (7).

Proof. Since $\varphi^{\prime \prime}(x), \psi^{\prime \prime}(x) \in C^{2}[0,1]$ and satisfy (7), by Steklov's theorem [37; 41] they admit expansions into absolutely and uniformly converging Fourier series in the eigenfunctions $\left\{y_{k}(x)\right\}$.

Thus, the series

$$
\varphi^{\prime \prime}(x)=-\sum_{k=1}^{\infty} \lambda_{k} \varphi_{k} y_{k}(x), \psi^{\prime \prime}(x)=-\sum_{k=1}^{\infty} \lambda_{k} \psi_{k} y_{k}(x)
$$

converges absolutely and uniformly.

From (11), (12), taking into account (14), since

$$
\lim _{k \rightarrow \infty} \lambda_{k}=+\infty,\left|e_{\alpha}\left(T, \lambda_{k}\right)\right| \leq M_{1},\left|e_{\alpha}\left(t, \lambda_{k}\right)\right| \leq M_{2}
$$

it is easy to get uniform estimates with respect to $k$

$$
\begin{gathered}
\left|u_{k}(t)\right| \leq C\left(\left|\varphi_{k}\right|+\left|\psi_{k}\right|+\left|U_{k}(t)\right|\right) ; \\
\left|D_{0+}^{\alpha} u_{k}(t)\right| \leq C\left(\left|\varphi_{k}\right|+\left|\psi_{k}\right|+\left|U_{k}(t)\right|\right)\left|\lambda_{k}\right| ; \\
\left|f_{k}\right| \leq C\left(\left|\varphi_{k}\right|+\left|\psi_{k}\right|+\left|U_{k}(T)\right|\right) .
\end{gathered}
$$

Hence, from the uniform and absolute convergence of series (15) there follow the convergence of series (9) and the belonging of the solution of (1), (2), (7) to the classes $u(x, t) \in C_{x, t}^{2,1}(\bar{\Omega}), f(x) \in C[0,1]$.

Let us prove the uniqueness of the solution. Suppose that there are two generalized solutions of the inverse problem (1), (2), (7): $\left(u_{1}(x, t), f_{1}(x)\right)$ and $\left(u_{2}(x, t), f_{2}(x)\right)$. Denote

$$
u(x, t)=u_{1}(x, t)-u_{2}(x, t), \quad f(x)=f_{1}(x)-f_{2}(x) .
$$

Then the functions $(u(x, t), f(x))$ satisfy equation (1), the boundary conditions (7) and the homogeneous conditions (2):

$$
u(x, 0)=0, \quad u(x, T)=0,0 \leq x \leq 1 .
$$

Let us show that the inverse problem $(1),(7),(16)$ has only zero solution. Let us introduce notations

$$
u_{k}(t)=\int_{0}^{1} u(x, t) y_{k}(x) d x, \quad f_{k}=\int_{0}^{1} f(x) y_{k}(x) d x, \quad(k=1,2, \ldots) .
$$

We apply the operator $D_{0+}^{\alpha}$ to $u_{k}(t)$. Then, using equation (1), by integrating by parts, we obtain a problem given by the equation

and the boundary conditions

$$
D_{0+}^{\alpha} u_{k}(t)+\lambda_{k} u_{k}(t)=f_{k},
$$

$$
u_{k}(0)=0, \quad u_{k}(T)=0 .
$$

General solution of equation (18) has the form (see [1], Eq. (25)):

$$
u_{k}(t)=\frac{f_{k} \alpha}{\Gamma(1+\alpha)} \int_{0}^{t}(t-\tau)^{\alpha-1} e_{\alpha}\left(\tau, \lambda_{k}\right) d \tau+u_{k}(0) e_{\alpha}\left(t, \lambda_{k}\right)
$$

Using the first of conditions (19), from here we have

$$
u_{k}(t)=\frac{f_{k} \alpha}{\Gamma(1+\alpha)} \int_{0}^{t}(t-\tau)^{\alpha-1} e_{\alpha}\left(\tau, \lambda_{k}\right) d \tau .
$$

Substituting this into the second condition of (19), we get

$$
\frac{f_{k} \alpha}{\Gamma(1+\alpha)} \int_{0}^{T}(T-\tau)^{\alpha-1} e_{\alpha}\left(\tau, \lambda_{k}\right) d \tau=0 .
$$


Since for $\mu>0$ and $0<\alpha \leq 1$ the function $e_{\alpha}(\tau, \mu)$ is absolutely monotone with respect to $\tau$ [36] and since $e_{\alpha}\left(0, \lambda_{k}\right)=1$, then the integral in $(21)$ is a strictly positive value. Consequently equation (21) holds if and only if $f_{k}=0$. But then from $(20)$ we get $u_{k}(t) \equiv 0$.

Therefore, using this result, from (17) we find

$$
\int_{0}^{1} u(x, t) y_{k}(x) d x \equiv 0, \quad \int_{0}^{1} f(x) y_{k}(x) d x=0, \quad(k=1,2, \ldots) .
$$

Further, by the completeness of system $\left\{y_{k}(x)\right\}$ in $L_{2}(0,1)$ we obtain $u(x, t) \equiv 0$ and $f(x) \equiv 0$ for all $(x, t) \in \bar{\Omega}$. The uniqueness of the generalized solution of the inverse problem (1), (2), (7) is proved. Theorem 1 is completely proved.

\section{Regular, but not strongly regular boundary conditions}

In [3] a class of regular but not strongly regular boundary conditions was described in a convenient form.

Lemma 1 [3]. If the boundary conditions (4) are regular but not strongly regular then the boundary conditions (3) reduce to

$$
\left\{\begin{aligned}
a_{1} u_{x}(0, t)+b_{1} u_{x}(1, t)+a_{0} u(0, t)+b_{0} u(1, t) & =0 ; \\
c_{0} u(0, t)+d_{0} u(1, t) & =0,
\end{aligned}\right.
$$

of one of the following four types:

$$
\begin{array}{lll}
I . & a_{1}+b_{1}=0, & c_{0}-d_{0} \neq 0 \\
I I . & a_{1}-b_{1}=0, & c_{0}+d_{0} \neq 0 \\
I I I . & c_{0}+d_{0}=0, & a_{1}-b_{1} \neq 0 \\
I V . & c_{0}-d_{0}=0, & a_{1}+b_{1} \neq 0 .
\end{array}
$$

Also in [4] the following result was proved.

Lemma 2 [4]. We can always equivalently reduce the solution of the problem (1)-(3) in the case of regular but not strongly regular conditions to solve successively two problems with strongly regular Sturm boundary conditions.

Using Lemma 2, we can obtain the existence of the solution of (1)-(3), as well as its uniqueness and smoothness, from Theorem 1 for the corresponding problems with strongly regular Sturm-type boundary conditions. In the next four sections, we will outline this method in more detail.

The method of solution, consisting in reducing the initial problem to a sequential solution of two initialboundary value problems with homogeneous boundary conditions of the Sturm type with respect to a spatial variable, will be formulated separately for each of types mentioned in Lemma 1.

\section{Reduction of the problem of type I to a sequential solution of two problems with homogeneous boundary conditions of the Sturm type}

Consider a problem of type I. Since $a_{1}+b_{1}=0$, and herewith $\left|a_{1}\right|+\left|b_{1}\right|>0$, then without loss of generality we can assume $a_{1}=-b_{1}=1$. Since $c_{0}-d_{0} \neq 0$, then without loss of generality we can assume $c_{0}-d_{0}=-1$. To simplify writing (omitting additional indexes) we denote $c_{0}=c$. Then $d_{0}=1+c$.

Therefore the problem of type I can be formulated in the form:

In $\Omega=\{(x, t): 0<x<1,0<t<T\}$ find a solution $u(x, t)$ of the fractional heat equation (1) satisfying the initial condition (2) and boundary conditions of type $I$ :

$$
\left\{\begin{array}{r}
u_{x}(0, t)-u_{x}(1, t)+a u(0, t)+b u(1, t)=0 \\
c u(0, t)+(1+c) u(1, t)=0
\end{array}\right.
$$

Here the coefficients $a, b, c$ of the boundary condition are arbitrary complex numbers.

To solve the problem we introduce the auxiliary functions:

$$
\begin{gathered}
v(x, t)=[u(x, t)+u(1-x, t)] / 2, \\
w(x, t)=u(x, t)-[1-(1+2 c)(2 x-1)] v(x, t) .
\end{gathered}
$$


Note that if the solution has been searched in the form of the sum of even and odd parts $u(x, t)=C(x, t)+S(x, t)$ in the initial version of the method (see [3]), then now in a variant suggested by us:

- the function $v(x, t)$ is even on the interval $0<x<1$, and is the even part of the function $u(x, t)$;

- and the function $w(x, t)$ is not the odd part of the function $u(x, t)$, though it is the odd function.

The last follows from the fact that $w(x, t)$ can be represented in the form

$$
w(x, t)=\frac{1}{2}[u(x, t)-u(1-x, t)]+(1+2 c)(2 x-1) v(x, t),
$$

that is, in the form of the sum of the odd part $\frac{1}{2}[u(x, t)-u(1-x, t)]$ of the function $u(x, t)$ and of the summand $(1+2 c)(2 x-1) v(x, t)$, which (it is easy to verify) is also the odd function on the whole interval $0<x<1$.

From (26) it is easy to see that if we find the functions $v(x, t)$ and $w(x, t)$, then the solution of the initial problem can be reestablished by the formula

$$
u(x, t)=w(x, t)+[1-(1+2 c)(2 x-1)] v(x, t) .
$$

Thus, if in the previous variant the solution is represented in the form of the sum of even and odd parts of the solution, then in the new variant suggested by us it is not quite so. In representation (28) the first summand is even on the interval $0<x<1$, and the second summand is neither even, nor odd for $1+2 c \neq 0$.

It is easy to make sure that the functions $v(x, t)$ and $w(x, t)$ are solutions of the fractional heat equations, satisfy the initial and homogeneous boundary conditions in $\Omega$.

For the function $v(x, t)$ we obtain the initial-boundary value problem which we need to solve first:

$$
\begin{array}{cc}
D_{0+}^{\alpha}(v(x, t)-v(x, 0))-v_{x x}(x, t)=f_{0}(x) ; \\
v(x, 0)=\varphi_{0}(x), \quad v(x, T)=\psi_{0}(x) \quad 0 \leq x \leq 1 ; \\
v_{x}(0, t)+[a(1+c)-b c] v(0, t)=0, \quad 0 \leq t \leq T ; \\
v_{x}(1, t)-[a(1+c)-b c] v(1, t)=0, \quad 0 \leq t \leq T .
\end{array}
$$

Here we use the notations

$$
\begin{gathered}
f_{0}(x)=\frac{1}{2}[f(x)+f(1-x)] \\
\varphi_{0}(x)=\frac{1}{2}[\varphi(x)+\varphi(1-x)], \quad \psi_{0}(x)=\frac{1}{2}[\psi(x)+\psi(1-x)] .
\end{gathered}
$$

Having the solution $v(x, t)$ of this problem, for the function $w(x, t)$ we get the initial-boundary value problem which we need to solve second:

$$
\begin{gathered}
D_{0+}^{\alpha}(w(x, t)-w(x, 0))-w_{x x}(x, t)=f_{1}(x)+F_{1}(x, t) \\
w(x, 0)=\varphi_{1}(x), \quad w(x, T)=\psi_{1}(x), \quad 0 \leq x \leq 1 \\
w(0, t)=0, \quad 0 \leq t \leq T \\
w(1, t)=0, \quad 0 \leq t \leq T .
\end{gathered}
$$

Here we use the notations

$$
\begin{gathered}
f_{1}(x)=f(x)-[1-(1+2 c)(2 x-1)] f_{0}(x), \quad F_{1}(x, t)=-4(1+2 c) v_{x}(x, t) \\
\varphi_{1}(x)=\varphi(x)-[1-(1+2 c)(2 x-1)] \varphi_{0}(x) \\
\psi_{1}(x)=\psi(x)-[1-(1+2 c)(2 x-1)] \psi_{0}(x)
\end{gathered}
$$

By direct checking from (33) and (39) it is easy to make sure that if the initial and final data $\varphi(x)$ and $\psi(x)$ of problem (1), (2), (24) satisfy necessary (classical and well-known) consistency conditions, then the initial and final data $\varphi_{0}(x), \varphi_{1}(x)$ and $\psi_{0}(x), \psi_{1}(x)$ also satisfy the necessary consistency conditions of their corresponding problems.

Thus the solution of the problem of type I $(1),(2),(24)$ is reduced to the sequential solution of two problems with homogeneous boundary conditions of the Sturm type with respect to the spatial variable: 
- At first for the function $v(x, t)$ we solve the initial-boundary value problem (29)-(32) with the homogeneous boundary conditions of the Sturm type with respect to the spatial variable;

- Then, using the obtained value $v(x, t)$, for the function $w(x, t)$ we solve the initial-boundary value problem (34)-(37) with the homogeneous boundary conditions of the Sturm type (in this particular case they are the Dirichlet conditions) with respect to the spatial variable.

Therefore the main result on the existence and uniqueness of the solution of the problem of type I (1), (2), (24) in classical and generalized senses follows from Theorem 1 on corresponding solvability of boundary value problems with conditions of the Sturm type. We will formulate this main result at once for all the four types of not strongly regular boundary conditions at the end of the paper.

\section{Reduction of the problem of type II to a sequential solution of two problems with homogeneous boundary conditions of the Sturm type}

Consider a problem of type II. Since $a_{1}-b_{1}=0$, and herewith $\left|a_{1}\right|+\left|b_{1}\right|>0$, then without loss of generality we can assume $a_{1}=b_{1}=1$. Since $c_{0}+d_{0} \neq 0$, then without loss of generality we can assume $c_{0}+d_{0}=1$. To simplify writing (omitting additional indexes) we denote $c_{0}=c$. Then $d_{0}=1-c$.

Therefore the problem of type I can be formulated in the form:

In $\Omega=\{(x, t): 0<x<1,0<t<T\}$ find a solution $u(x, t)$ of the fractional heat equation (1) satisfying the initial condition (2) and boundary conditions of type II:

$$
\left\{\begin{aligned}
u_{x}(0, t)+u_{x}(1, t)+a u(0, t)+b u(1, t) & =0 \\
c u(0, t)+(1-c) u(1, t) & =0 .
\end{aligned}\right.
$$

Here the coefficients $a, b, c$ of the boundary condition are arbitrary complex numbers.

We introduce the auxiliary functions:

$$
\begin{gathered}
v(x, t)=\frac{1}{2}[u(x, t)-u(1-x, t)], \\
w(x, t)=u(x, t)-[1-(1-2 c)(2 x-1)] v(x, t) .
\end{gathered}
$$

Note that if the solution has been searched in the form of the sum of even and odd parts $u(x, t)=C(x, t)+S(x, t)$ in the initial version of the method (see [3]), then in a new variant suggested by us:

- the function $v(x, t)$ is odd on the interval $0<x<1$, and is the odd part of the function $u(x, t)$;

- and the function $w(x, t)$ is not the even part of the function $u(x, t)$, though it is the even function.

The last follows from the fact that $w(x, t)$ can be represented in the form

$$
w(x, t)=\frac{1}{2}[u(x, t)+u(1-x, t)]+(1-2 c)(2 x-1) v(x, t),
$$

that is, in the form of the sum of the even part $\frac{1}{2}[u(x, t)-u(1-x, t)]$ of the function $u(x, t)$ and the summand $(1-2 c)(2 x-1) v(x, t)$, which (it is easy to verify) is also the even function on the interval $0<x<1$.

From (42) it is easy to find the functions $v(x, t)$ and $w(x, t)$, then the solution of the initial problem can be reestablished by the formula

$$
u(x, t)=w(x, t)+[1-(1-2 c)(2 x-1)] v(x, t) .
$$

Thus if in the previous variant of the method the solution is represented in the form of the sum of the even and odd parts of the solution, then in the new variant suggested by us it is not quite so. In representation (44) the first summand is even on the interval $0<x<1$, and the second summand is neither even, nor odd for $1-2 c \neq 0$.

For the function $v(x, t)$ we obtain the initial-boundary value problem which we need to solve first:

$$
\begin{gathered}
D_{0+}^{\alpha}(v(x, t)-v(x, 0))-v_{x x}(x, t)=f_{0}(x), \\
v(x, 0)=\varphi_{0}(x), \quad v(x, T)=\psi_{0}(x) \quad 0 \leq x \leq 1, \\
v_{x}(0, t)+[a(1-c)-b c] v(0, t)=0, \quad 0 \leq t \leq T, \\
v_{x}(1, t)-[a(1-c)-b c] v(1, t)=0, \quad 0 \leq t \leq T .
\end{gathered}
$$


Here we use the notations

$$
\begin{gathered}
f_{0}(x)=\frac{1}{2}[f(x)-f(1-x)], \\
\varphi_{0}(x)=\frac{1}{2}[\varphi(x)-\varphi(1-x)], \quad \psi_{0}(x)=\frac{1}{2}[\psi(x)-\psi(1-x)] .
\end{gathered}
$$

Having the solution $v(x, t)$ of this problem, for the function $w(x, t)$ we get the initial-boundary value problem which we need to solve second:

$$
\begin{gathered}
D_{0+}^{\alpha}(w(x, t)-w(x, 0))-w_{x x}(x, t)=f_{1}(x)+F_{1}(x, t), \\
w(x, 0)=\varphi_{1}(x), \quad w(x, T)=\psi_{1}(x), \quad 0 \leq x \leq 1, \\
w(0, t)=0, \quad 0 \leq t \leq T \\
w(1, t)=0, \quad 0 \leq t \leq T .
\end{gathered}
$$

Here we use the notations

$$
\begin{gathered}
f_{1}(x)=f(x)-[1-(1-2 c)(2 x-1)] f_{0}(x), \quad F_{1}(x, t)=-4(1-2 c) v_{x}(x, t), \\
\varphi_{1}(x)=\varphi(x)-[1-(1-2 c)(2 x-1)] \varphi_{0}(x) \\
\psi_{1}(x)=\psi(x)-[1-(1-2 c)(2 x-1)] \psi_{0}(x) .
\end{gathered}
$$

By direct checking from (49) and (55) it is easy to make sure that if the initial and final data $\varphi(x)$ and $\psi(x)$ of problem (1), (2), (40) satisfy necessary (classical and well-known) consistency conditions, then the initial and final data $\varphi_{0}(x), \varphi_{1}(x)$ and $\psi_{0}(x), \psi_{1}(x)$ also satisfy the necessary consistency conditions of their corresponding problems.

Thus the solution of the problem of type II (1), (2), (40) is reduced to the sequential solution of two problems with homogeneous boundary conditions of the Sturm type with respect to the spatial variable:

- At first for the function $v(x, t)$ we solve the initial-boundary value problem (45)-(48) with the homogeneous boundary conditions of the Sturm type (in this case they are the Dirichlet conditions) with respect to the spatial variable;

- Then, using the obtained value $v(x, t)$, for the function $w(x, t)$ we solve the initial-boundary value problem (50)-(53) with the homogeneous boundary conditions of the Sturm type (in this case with conditions of the Dirichlet problem) with respect to the spatial variable.

Therefore the main result on the existence and uniqueness of the solution of the problem of type II (1), (2), (40) in classical and generalized senses follows from Theorem 1 on corresponding solvability of boundary value problems with conditions of the Sturm type. We will formulate this main result at once for all the four types of not strongly regular boundary conditions at the end of the paper.

\section{Reduction of the problem of type III to a sequential solution of two problems with homogeneous boundary conditions of the Sturm type}

Consider a problem of type III. Since $c_{0}+d_{0}=0$, and herewith $\left|c_{0}\right|+\left|d_{0}\right|>0$, then without loss of generality we can assume $c_{0}=-d_{0}=1$. Since $a_{1}-b_{1} \neq 0$, then without loss of generality we can assume $a_{1}-b_{1}=-1$. To simplify writing (omitting additional indexes) we denote $a_{1}=c$. Then $b_{1}=1+c$.

Therefore the problem of type III can be formulated in the form:

In $\Omega=\{(x, t): 0<x<1,0<t<T\}$ find a solution $u(x, t)$ of the fractional heat equation (1) satisfying the initial condition (2) and the boundary condition of type III:

$$
\left\{\begin{aligned}
c u_{x}(0, t)+(1+c) u_{x}(1, t)+a u(0, t) & =0 \\
u(0, t)-u(1, t) & =0 .
\end{aligned}\right.
$$

Here the coefficients $a, b, c$ of the boundary condition are arbitrary complex numbers.

We introduce the auxiliary functions:

$$
\begin{gathered}
v(x, t)=\frac{1}{2}[u(x, t)-u(1-x, t)] ; \\
w(x, t)=u(x, t)-[1-(1+2 c)(2 x-1)] v(x, t) .
\end{gathered}
$$


Note that if the solution has been searched in the form of a sum of even and odd parts $u(x, t)=$ $=C(x, t)+S(x, t)$ in the initial version of the method (see [3]), then in a variant suggested by us:

- the function $v(x, t)$ is odd on the interval $0<x<1$, and is the odd part of the function $u(x, t)$;

- and the function $w(x, t)$ is not the even part of the function $u(x, t)$, though it is the even function.

The last follows from the fact that $w(x, t)$ can be represented in the form

$$
w(x, t)=\frac{1}{2}[u(x, t)+u(1-x, t)]+(1+2 c)(2 x-1) v(x, t),
$$

that is, in the form of the sum of the even part $\frac{1}{2}[u(x, t)+u(1-x, t)]$ of the function $u(x, t)$ and the summand $(1+2 c)(2 x-1) v(x, t)$, which (it is easy to verify) is also the even function on the interval $0<x<1$.

From (58) it is easy to see that if we find the functions $v(x, t)$ and $w(x, t)$, then the solution of the initial problem can be reestablished by the formula

$$
u(x, t)=w(x, t)+[1-(1+2 c)(2 x-1)] v(x, t) .
$$

Thus if in the previous variant of the method the solution is represented in the form of the sum of the even and odd parts of the solution, then in the new variant suggested by us it is not quite so. In representation (60) the first summand is even on the interval $0<x<1$, and the second summand is neither even, nor odd for $(1+2 c) \neq 0$.

For the function $v(x, t)$ we obtain the initial-boundary value problem which we need to solve first:

$$
\begin{gathered}
D_{0+}^{\alpha}(v(x, t)-v(x, 0))-v_{x x}(x, t)=f_{0}(x) ; \\
v(x, 0)=\varphi_{0}(x), \quad v(x, T)=\psi_{0}(x) \quad 0 \leq x \leq 1 ; \\
v(0, t)=0, \quad 0 \leq t \leq T ; \\
v(1, t)=0, \quad 0 \leq t \leq T .
\end{gathered}
$$

Here we use the notations

$$
\begin{gathered}
f_{0}(x)=\frac{1}{2}[f(x)-f(1-x)] ; \\
\varphi_{0}(x)=\frac{1}{2}[\varphi(x)-\varphi(1-x)], \quad \psi_{0}(x)=\frac{1}{2}[\psi(x)-\psi(1-x)] .
\end{gathered}
$$

Having the solution $v(x, t)$ of this problem, for the function $w(x, t)$ we get the initial-boundary value problem which we need to solve second:

$$
\begin{gathered}
D_{0+}^{\alpha}(w(x, t)-w(x, 0))-w_{x x}(x, t)=f_{1}(x)+F_{1}(x, t) ; \\
w(x, 0)=\varphi_{1}(x), \quad w(x, T)=\psi_{1}(x), \quad 0 \leq x \leq 1 ; \\
w_{x}(0, t)-a w(0, t)=0, \quad 0 \leq t \leq T ; \\
w_{x}(1, t)+a w(1, t)=0, \quad 0 \leq t \leq T .
\end{gathered}
$$

Here we use the notations

$$
\begin{gathered}
f_{1}(x)=f(x)-[1-(1+2 c)(2 x-1)] f_{0}(x), \quad F_{1}(x, t)=-4(1+2 c) v_{x}(x, t) ; \\
\varphi_{1}(x)=\varphi(x)-[1-(1+2 c)(2 x-1)] \varphi_{0}(x) ; \\
\psi_{1}(x)=\psi(x)-[1-(1+2 c)(2 x-1)] \psi_{0}(x) .
\end{gathered}
$$

By direct checking from (65) and (71) it is easy to make sure that if the initial and final data $\varphi(x)$ and $\psi(x)$ of problem (1), (2), (56) satisfy necessary (classical and well-known) consistency conditions, then the initial and final data $\varphi_{0}(x), \varphi_{1}(x)$ and $\psi_{0}(x), \psi_{1}(x)$ also satisfy the necessary consistency conditions of their corresponding problems.

Thus the solution of the problem of type III (1), (2), (56) is reduced to the sequential solution of two problems with homogeneous boundary conditions of the Sturm type with respect to the spatial variable: 
- At first for the function $v(x, t)$ we solve the initial-boundary value problem (61)-(94) with the homogeneous boundary conditions of the Sturm type (in this case with conditions of the Dirichlet problem) with respect to the spatial variable;

- Then, using the obtained value $v(x, t)$, for the function $w(x, t)$ we solve the initial-boundary value problem (66)-(69) with the homogeneous boundary conditions of the Sturm type with respect to the spatial variable.

Therefore the main result on the existence and uniqueness of the solution of the problem of type III (1), (2), (56) in classical and generalized senses follows from the Theorem 1 on corresponding solvability of boundary value problems with conditions of the Sturm type. We will formulate this main result at once for all the four types of not strongly regular conditions at the end of the paper.

\section{Reduction of the problem of type IV to a sequential solution of two problems with homogeneous boundary conditions of the Sturm type}

Consider a problem of type IV. Since $c_{0}-d_{0}=0$, and herewith $\left|c_{0}\right|+\left|d_{0}\right|>0$, then without loss of generality we can assume $c_{0}=d_{0}=1$. Since $a_{1}+b_{1} \neq 0$, then without loss of generality we can assume $a_{1}+b_{1}=1$. To simplify writing (omitting additional indexes) we denote $a_{1}=c$. Then $b_{1}=1-c$.

Therefore the problem of type IV can be formulated in the form:

In $\Omega=\{(x, t), 0<x<1,0<t<T\}$ find a solution $u(x, t)$ of the fractional heat equation (1) satisfying the initial condition (2) and the boundary conditions of type $I V$ :

$$
\left\{\begin{aligned}
c u_{x}(0, t)+(1-c) u_{x}(1, t)+a u(0, t) & =0 \\
u(0, t)+u(1, t) & =0 .
\end{aligned}\right.
$$

Here the coefficients $a, b, c$ of the boundary condition are arbitrary complex numbers.

We introduce the auxiliary functions:

$$
\begin{gathered}
v(x, t)=\frac{1}{2}[u(x, t)+u(1-x, t)] \\
w(x, t)=u(x, t)-[1-(1-2 c)(2 x-1)] v(x, t) .
\end{gathered}
$$

Note that if the solution has been searched in the form of the sum of the even and odd parts $u(x, t)=C(x, t)+S(x, t)$ in the initial version of the method (see [3]), then in the variant suggested by us:

- the function $v(x, t)$ is even on the interval $0<x<1$, and is the even part of the function $u(x, t)$;

- and the function $w(x, t)$ is not the odd part of the function $u(x, t)$, though it is the odd function.

The last follows from the fact that $w(x, t)$ can be represented in the form

$$
w(x, t)=\frac{1}{2}[u(x, t)-u(1-x, t)]+(1-2 c)(2 x-1) v(x, t),
$$

that is, in the form of the sum of the odd part $\frac{1}{2}[u(x, t)-u(1-x, t)]$ of the function $u(x, t)$ and the summand $(1-2 c)(2 x-1) v(x, t)$, which (it is easy to verify) is also the odd function on the interval $0<x<1$.

From (74) it is easy to see that if we find the functions $v(x, t)$ and $w(x, t)$, then the solution of the initial problem can be reestablished by the formula

$$
u(x, t)=w(x, t)+[1-(1-2 c)(2 x-1)] v(x, t) .
$$

Thus if in the previous variant of the method the solution is represented in the form of the sum of the even and odd parts of the solution, then in the new variant suggested by us it is not quite so. In representation (76) the first summand is odd on the interval $0<x<1$, and the second summand is neither even, nor odd for $(1-2 c) \neq 0$.

For the function $v(x, t)$ we obtain the initial-boundary value problem which we need to solve first:

$$
\begin{gathered}
D_{0+}^{\alpha}(v(x, t)-v(x, 0))-v_{x x}(x, t)=f_{0}(x) \\
v(x, 0)=\varphi_{0}(x), \quad v(x, T)=\psi_{0}(x) \quad 0 \leq x \leq 1 \\
v(0, t)=0, \quad 0 \leq t \leq T \\
v(1, t)=0, \quad 0 \leq t \leq T .
\end{gathered}
$$


Here we use the notations

$$
\begin{gathered}
f_{0}(x)=\frac{1}{2}[f(x)+f(1-x)], \\
\varphi_{0}(x)=\frac{1}{2}[\varphi(x)+\varphi(1-x)], \quad \psi_{0}(x)=\frac{1}{2}[\psi(x)+\psi(1-x)] .
\end{gathered}
$$

Having the solution $v(x, t)$ of this problem, for the function $w(x, t)$ we get the initial-boundary value problem which we need to solve second:

$$
\begin{gathered}
D_{0+}^{\alpha}(w(x, t)-w(x, 0))-w_{x x}(x, t)=f_{1}(x)+F_{1}(x, t) \\
w(x, 0)=\varphi_{1}(x), \quad w(x, T)=\psi_{1}(x), \quad 0 \leq x \leq 1 \\
w_{x}(0, t)+a w(0, t)=0, \quad 0 \leq t \leq T \\
w_{x}(1, t)-a w(1, t)=0, \quad 0 \leq t \leq T .
\end{gathered}
$$

Here we use the notations

$$
\begin{gathered}
f_{1}(x)=f(x)-[1-(1-2 c)(2 x-1)] f_{0}(x), \quad F_{1}(x, t)=-4(1-2 c) v_{x}(x, t) ; \\
\varphi_{1}(x)=\varphi(x)-[1-(1-2 c)(2 x-1)] \varphi_{0}(x) \\
\psi_{1}(x)=\psi(x)-[1-(1-2 c)(2 x-1)] \psi_{0}(x) .
\end{gathered}
$$

By direct checking from (81) and (87) it is easy to make sure that if the initial and final data $\varphi(x)$ and $\psi(x)$ of problem (1), (2), (72) satisfy necessary (classical and well-known) consistency conditions, then the initial and final data $\varphi_{0}(x), \varphi_{1}(x)$ and $\psi_{0}(x), \psi_{1}(x)$ also satisfy the necessary consistency conditions of their corresponding problems.

Thus the solution of the problem of type IV (1), (2), (72) is reduced to the sequential solution of two problems with homogeneous boundary conditions of the Sturm type with respect to the spatial variable:

- At first for the function $v(x, t)$ we solve the initial-boundary value problem (77)-(80) with the homogeneous boundary conditions of the Sturm type (in this case with boundary conditions of Dirichlet) with respect to the spatial variable;

- Then using the obtained value $v(x, t)$, for the function $w(x, t)$ we solve the initial-boundary value problem (82)-(85) with the homogeneous boundary conditions of the Sturm type with respect to the spatial variable.

Therefore the main result on the existence and uniqueness of the solution of the problem of type IV (1), (2), (72) in classical and generalized senses follows from the Theorem 1 on corresponding solvability of boundary value problems with conditions of the Sturm type. We will formulate this result as well as the results of sections 4,5 and 6 at once for all the four types of not strongly regular boundary conditions in the next section.

\section{Formulation of the main result on solvability of the fractional heat equation with not strongly regular boundary conditions}

For completeness of exposition we once again formulate the problem under consideration:

In $\Omega=\{(x, t), 0<x<1,0<t<T\}$ find a right-hand side $f(x)$ of the fractional heat equation

$$
D_{0+}^{\alpha}(u(x, t)-u(x, 0))-u_{x x}(x, t)=f(x)+F(x, t),
$$

and its solutions $u(x, t)$ satisfying the initial and final conditions

$$
u(x, 0)=\varphi(x), \quad u(x, T)=\psi(x), 0 \leq x \leq 1,
$$

and not strongly regular boundary conditions of the general form

$$
\left\{\begin{array}{r}
a_{1} u_{x}(0, t)+b_{1} u_{x}(1, t)+a_{0} u(0, t)+b_{0} u(1, t)=0 \\
c_{0} u(0, t)+d_{0} u(1, t)=0 .
\end{array}\right.
$$

The coefficients $a_{k}, b_{k}, c_{k}, d_{k}(k=0,1)$ of the boundary condition (90) are arbitrary real numbers, and $\varphi(x), \psi(x)$ and $F(x, t)$ are given functions. 
We consider boundary conditions which are regular, but not strongly regular, that is, cases when one of the conditions holds:

$$
\begin{array}{lll}
I . & a_{1}+b_{1}=0, & c_{0}-d_{0} \neq 0 ; \\
I I . & a_{1}-b_{1}=0, & c_{0}+d_{0} \neq 0 ; \\
I I I . & c_{0}-d_{0}=0, & a_{1}+b_{1} \neq 0 ; \\
I V . & c_{0}+d_{0}=0, & a_{1}-b_{1} \neq 0 .
\end{array}
$$

As shown in sections $4-8$, the solution to the problem with the not strongly regular boundary conditions of all the four types has been reduced to the sequential solution of two problems with the homogeneous boundary conditions of the Sturm type with respect to the spatial variable. Herewith one of these problems has the Dirichlet boundary conditions with respect to the spatial variable, that is, it is a classical first initial-boundary value problem.

On the basis of this fact, using the results from Theorem 1, now we can easily formulate a theorem on well-posedness of the general problem with the not strongly regular boundary conditions with respect to the spatial variable.

Theorem 2. Let one of conditions (91) hold. That is, the boundary conditions (90) are regular, but not strongly regular. If $F(x, t) \in C^{2}(\bar{\Omega}), \varphi(x), \psi(x) \in C^{4}[0,1]$ and the functions $F(x, t), \varphi(x), \psi(x), \varphi^{\prime \prime}(x)$ and $\psi^{\prime \prime}(x)$ satisfy (4) then there exists the unique classical solution $u(x, t) \in C_{x, t}^{2,1}(\bar{\Omega}), f(x) \in C[0,1]$ to the inverse problem (1), (2), (90).

Note that by this method, problem (1), (2), (90) has been solved regardless whether the corresponding spectral problem for the operator of twofold differentiation with the not strongly regular boundary conditions (4) has the basis property of root functions.

This research is financially supported by a grant AP05133271 and by the target program BR05236656 from the Science Committee from the Ministry of Science and Education of the Republic of Kazakhstan.

\section{References}

1 Kirane, M., \& Malik, S.A. (2010). Determination of an unknown source term and the temperature distribution for the linear heat equation involving frac-tional derivative in time, 2010. hal.archivesouvertes. Retrieved from https://hal.archives-ouvertes.fr/hal-00549130.

2 Naimark, M.A. (1969). Linear differential operators (Russian). Moscow: Nauka.

3 Orazov, I., \& Sadybekov, M.A. (2012). On a class of problems of determining the temperature and density of heat sources given initial and final temperature. Siberian Mathematical Journal, 53, 1, $146-151$.

4 Sadybekov, M.A. (2017). Initial-boundary value problem for a heat equation with not strongly regular boundary conditions. Functional analysis in interdisciplinary applications, Springer Proc. Math. Stat., 216, Springer, Cham, 330-348.

5 Orazov, I., \& Sadybekov, M.A. (2012). One nonlocal problem of determination of the temperature and density of heat sources. Russian Math., 56, 2, 60-64.

6 Ivanchov, M.I. (1993). Some inverse problems for the heat equation with nonlocal boundary conditions, Ukrainian Mathematical Journal, 45, 8, 1186-1192.

7 Kaliev, I.A., \& Sabitova, M.M. (2010). Problems of determining the temperature and density of heat sources from the initial and final temperatures, Journal of Applied and Industrial Mathematics, 4, 3, $332-339$.

8 Kaliev I.A., Mugafarov, M.F., \& Fattahova, O.V. (2011). Inverse problem for forwardbackward parabolic equation with generalized conjugation conditions, Ufa Mathematical Journal, 3, 2, 33-41.

9 Kirane, M., \& Malik, A.S. (2011). Determination of an unknown source term and the temperature distribution for the linear heat equation involving fractional derivative in time, Appl. Math. Comput., 218, 1, 163-170.

10 Ismailov, M.I., \& Kanca, F. (2012). The inverse problem of finding the time-dependent diffusion coefficient of the heat equation from integral overdetermination data, Inverse Problems in Science and Engineering, 20, 463-476. 
11 Kirane, M., Malik, A.S., \& Al-Gwaiz, M.A. (2013). An inverse source problem for a two dimensional time fractional diffusion equation with nonlocal boundary conditions, Math. Methods Appl. Sci., 36, 9, 1056-1069.

12 Ashyralyev, A., \& Sharifov, Y.A. (2013). Counterexamples in inverse problems for parabolic, elliptic, and hyperbolic equations, Advances in Difference Equations, 173, 797-810.

13 Kanca, F. (2013). Inverse coefficient problem of the parabolic equation with periodic boundary and integral overdetermination conditions, Abstract and Applied Analysis, Article ID659804, 1-7.

14 Lesnic, D., Yousefi, S.A., \& Ivanchov, M. (2013). Determination of a time-dependent diffusivity form nonlocal conditions, Journal of Applied Mathematics and Computation, 41, 301-320.

15 Miller, L., \& Yamamoto, M. (2013). Coefficient inverse problem for a fractional diffusion equation, Inverse Problems, 29, 74, 1-8.

16 Li, G., Zhang, D., Jia, X., \& Yamamoto, M. (2013). Simultaneous inversion for the space-dependent diffusion coefficient and the fractional order in the time-fractional diffusion equation, Inverse Problems, 29, 6, 065014, 36.

17 Kostin, A.B. (2014). Counterexamples in inverse problems for parabolic, elliptic, and hyperbolic equations, Computational Mathematics and Mathematical Physics, 54, 5, 797-810.

18 Ashyralyev, A., \& Hanalyev, A. (2014). Well-posedness of nonlocal parabolic differential problems with dependent operators, The Scientific World Journal, Article ID 519814, 1-11.

19 Ashyralyev, A., \& Sarsenbi, A. (2015). Well-posedness of a parabolic equation with nonlocal boundary condition, Boundary Value Problems, 1.

20 Orazov, I., \& Sadybekov, M.A. (2015). On an inverse problem of mathematical modeling of the extraction process of polydisperse porous materials, AIP Conference Proceedings, 1676, 020005.

21 Orazov, I., \& Sadybekov, M.A. (2015). One-dimensional diffusion problem with not strengthened regular boundary conditions, AIP Conference Proceedings, 1690, 040007.

22 Tuan, N.H., Hai, D.N.D., Long, L.D., Thinh, N.V., \& Kirane, M. (2017). On a Riesz-Feller space fractional backward diffusion problem with a nonlinear source, J. Comput. Appl. Math., 312, 103-126.

23 Sadybekov, M., Oralsyn, G., \& Ismailov, M. (2017). An inverse problem of finding the time-dependent heat transfer coefficient from an integral condition, International Journal of Pure and Applied Mathematics, 113, 4, 139-149.

24 Tuan, N.H., Kirane, M., Hoan, L.V. C., \& Long, L.D. (2017). Identification and regularization for unknown source for a time-fractional diffusion equation, Computers \& Mathematics with Applications, 73, 6, 931950 .

25 Torebek, B.T., \& Tapdigoglu, R. Some inverse problems for the nonlocal heat equation with Caputo fractional derivative, Math Meth Appl Sci., 2017, 40, 6468-6479.

26 Kirane, M., Samet, B., \& Torebek, B.T. (2017). Determination of an unknown source term temperature distribution for the sub-diffusion equation at the initial and final data, Electronic Journal of Differential Equations, 25\%, 1-13.

27 Taki-Eddine, O., \& Abdelfatah, B. (2018). On determining the coefficient in a parabolic equation with nonlocal boundary and integral condition, Electronic Journal of Mathematical Analysis and Applications, $6,1,94-102$.

28 Sadybekov, M.A., Torebek, B.T., \& Turmetov, B. (2017). Kh. Representation of the Green's function of the exterior Neumann problem for the Laplace operator, Siberian Mathematical Journal, 58, 1, $153-158$.

29 Kal'menov, T.Sh., \& Sadybekov, M.A. (2017). On a Frankl-type problem for a mixed parabolic-hyperbolic equation, Siberian Mathematical Journal, 58, 2, 227-231.

30 Sadybekov, M.A., Dildabek, G., \& Tengayeva, A. (2017). Constructing a Basis from Systems of Eigenfunctions of one not Strengthened Regular Boundary Value Problem, Filomat, 31, 4, 981-987.

31 Sadybekov, M.A., \& Imanbaev, N.S. (2017). A regular differential operator with perturbed boundary condition, Mathematical Notes, 101, 5-6, 878-887.

32 Karachik, V.V., Sadybekov, M.A., \& Torebek, B.T. (2015). Uniqueness of solutions to boundary-value problems for the biharmonic equation in a ball, Electronic Journal of Differential Equations, $244,1-9$.

33 Sadybekov, M.A., Dildabek, G., \& Ivanova, M.B. (2018). Spectral properties of a Frankl type problem for parabolic-hyperbolic equations, Electronic Journal of Differential Equations, 65, 1-11. 
34 Sadybekov, M.A., Oralsyn, G., \& Ismailov, M. (2018). Determination of a time-dependent heat source under not strengthened regular boundary and integral overdetermination conditions, Filomat, 32, 3, 809814.

35 Sadybekov, M., Dildabek, G., \& Ivanova, M. (2018). On an inverse problem of reconstructing a heat conduction process from nonlocal data, Advances in Mathematical Physics, Art. ID 8301656, 1-8.

36 Gorenflo, R., \& Mainardi, F. (1997). Fractional Calculus: integral and differential equations of fractional order, in: A. Carpinteri, F. Mainardi (Eds.), Fractals and Fractional Calculus in Continuum Mechanics, Springer Verlag, Wien, 223-276.

37 Levitan, B.M., \& Sargsyan, I.S. (1988). Sturm-Liouville and Dirac Operators. Moscow: Nauka [in Russian].

А.С. Эрдоган, Д. Кусмангазинова, И. Оразов, М.А. Садыбеков

\title{
Бөлшек жылуөткізгіштік үрдісі көзінің тығыздығын бастапқы және ақырғы температуралары бойынша қалпына келтіру есебі туралы
}

\begin{abstract}
Мақалада жұмыста бөлшек жылуөткізгіштік теңдеуі үшін кері есептер қарастырылған. Уақыт бойынша Риман-Лиувилл мағынасындағы бөлшек ретті туындылар пайдаланылды. Берілген теңдеудің шешімімен қатар, теңдеудің оң жағындағы белгісіз болып отырған функцияны анықтау мәселесі шешімін тапқан. Бұл жерде теңдеудің оң жағындағы белгісіз функция уақыт айнымалысынан тәуелсіз болады. Бастапқы және ақырғы температураларға қатысты бөлшек жылуөткізгіштік үрдісі көзінің тығыздығын және температурасын анықтау мәселесін модельдейтін есеп зерттелген. Қатаң регулярлы болмайтын кеңістіктегі айнымалылар бойынша жалпы түрдегі шеттік есептерге қатысты мәселелер қарастырылған. Есептің классикалық шешімінің бар және жалғыз болатындығы көрсетілген. Есепке қатысты еселеп дифференциалдау операторы үшін шеттік шарттары қатаң регулярлы емес спектралдық есептің меншікті функциялары базис болмайтын болса да, есептің шешімі табылған.

Kiлm сөздер: кері есеп, жылуөткізгіштік теңдеуі, бөлшек жылуөткізгіштік, қатаң регулярлы емес шеттік шарттар, айнымалыларды айыру тәсілі.
\end{abstract}

А.С. Эрдоган, Д. Кусмангазинова, И. Оразов, М.А. Садыбеков

Об одной задаче восстановления плотности источников процесса дробной теплопроводности по начальной и конечной температурам

В статье рассмотрены обратные задачи для дробного уравнения теплопроводности, где дробная производная по времени понимается в смысле Римана-Лиувилля. Вместе с решением этого уравнения необходимо найти неизвестную правую часть, зависящую только от пространственной переменной. Рассмотрена задача, моделирующая процесс определения температуры и плотности источников в процессе дробной теплопроводности относительно заданных начальных и конечных температур. Исследованы проблемы с общими граничными условиями относительно пространственной переменной, которые не являются усиленно регулярными. Доказаны существование и единственность классического решения задачи. Задача решается независимо от того, что соответствующая спектральная задача для оператора кратного дифференцирования с неусиленно регулярными граничными условиями может не иметь свойства базисности корневых функций.

Ключевые слова: обратная задача, уравнение теплопроводности, дробная теплопроводность, неусиленно регулярные граничные условия, метод разделения переменных. 